\title{
Multivariate Adaptive Regression Splines pada Kasus Inflasi di Indonesia Tahun 2005-2018
}

\author{
Nurhaerunisa Widagdo*, Muhammad Kasim Aidid, \& Sudarmin \\ Program Studi Statistika, Fakultas Matematika dan Ilmu Pengetahuan Alam, Universitas Negeri Makassar, Indonesia
}

Keywords: Inflasi, MARS, RPR, $\mathrm{BF}, \mathrm{MI}, \mathrm{MO}, \mathrm{GCV}$.

\begin{abstract}
:
Kegiatan perekonomian suatu negara dipengaruhi oleh inflasi yang terjadi pada negara tersebut. Tingkat inflasi Indonesia yang fluktuatif, cenderung tidak stabil, mempengaruhi kehidupan sosial dan ekonomi masyarakat. Sehingga penting untuk mengetahui faktor-faktor yang berpengaruh terhadap inflasi serta pemodelan faktor-faktor berpengaruh tersebut dan hubungannya terhadap inflasi. Mengidentifikasi hubungan inflasi dan faktor penyebabnya dilakukan menggunakan pemodelan Multivariate Adaptive Regression Splines (MARS). MARS merupakan jenis regeresi nonparametrik yang menggabungkan prinsip Recursive Partitioning Regression (RPR) dan spline, fleksibel dalam memodelkan data sehingga memberikan hasil pemodelan data yang cukup akurat serta dapat menangani data berdimensi tinggi, yaitu data dengan jumlah peubah prediktor $3 \leq x \leq 20$ dan ukuran data sampel $50 \leq n \leq$ 1000. Model MARS diperoleh berdasarkan kombinasi nilai BF, MI, dan MO yang memiliki nilai Generalized Cross Validation (GCV) terkecil. Pada penelitian ini digunakan enam peubah prediktor sebagai faktor yang mempengaruhi inflasi dengan data sampel sebesar 168 sampel. Hasil penelitian menunjukkan bahwa peubah Indeks Harga Perdagangan Besar (IHPB), BI Rate, Nilai Tukar IDR-USD, dan Uang Beredar adalah faktor-faktor yang berpengaruh terhadap inflasi berdasarkan model terbaik MARS dengan $\mathrm{BF}=24, \mathrm{MI}=3, \mathrm{MO}=1, \mathrm{GCV}=0,772$, $\mathrm{MSE}=0,391$, dan $\mathrm{R}^{2}=0,968$.
\end{abstract}

\section{Pendahuluan}

Permasalahan sosial dan ekonomi selalu menjadi perhatian negara di dunia. Sementara terdapat satu indikator maroekonomi yang sangat berhubungan dengan kedua permasalahan tersebut, yaitu inflasi. Inflasi merupakan kecenderungan meningkatnya harga-harga barang dan jasa di pasaran dalam kurun waktu tertentu, dan dipengaruhi oleh berbagai kegiatan ekonomi lainnya. Inflasi menunjukkan keadaan ekonomi suatu negara, apakah negara tersebut mengalami perekonomian yang berjalan baik atau tidak. Sehingga inflasi yang stabil merupakan prasyarat bagi pertumbuhan ekonomi yang berkesinambungan hingga dapat memberikan manfaat bagi peningkatan kesejahteraan masyarakat.

Berdasarkan publikasi Badan Pusat Statistik (2018), tingkat inflasi di Indonesia pada tahun 2017 ialah 3,61\%, yaiu lebih tinggi 0,59\% dibandingkan tingkat inflasi pada tahun sebelumnya. Selanjutnya, dilansir dari Bank Indonesia, sasaran inflasi di Indonesia pada tahun 2019 ialah sebesar 3,5\%. Adanya kecenderungan tingkat inflasi Indonesia yang selalu berubah-ubah, maka dianggap perlu untuk mengetahui faktor-faktor yang berpengaruh terhadap perubahan tingkat inflasi. Berdasarkan hal tersebut, maka digunakan Multivariate Adaptive Regression Splines (MARS). MARS merupakan jenis regresi nonparametrik yang mengkombinasikan prinsip Recursive Partitioning

\footnotetext{
* Corresponding author.

E-mail address: nisa1.widagdo@gmail.com
} 
Regression dan spline, sehingga memiliki fleksibilitas yang tinggi untuk memodelkan data berdimensi tinggi dan mengatasi kontinuitas pada kurva regresi.

\section{Tinjauan Pustaka}

Inflasi merupakan kecenderungan meningkatnya harga sekelompok barang dan jasa secara umum dalam kurun waktu tertentu. Perhitungan inflasi dilakukan berdasarkan waktu bulanan, triwulan, atau tahunan. Berdasarkan asal terjadinya, inflasi dibedakan atas domestic inflation dan imported inflation (Khalwaty, 2000). Domestic inflation disebabkan karena adanya kejutan dari dalam negeri, berupa kebijakan yang dikeluarkan pemerintah atau perilaku masyarakat dalam kegiatan ekonomi. Imported inflation terjadi akibat pengaruh kenaikan harga dari luar negeri, terkhusus kenaikan harga barang impor dan bahan baku industri karena belum mampu melakukan produksi di dalam negeri. Sedangkan berdasarkan jenis penyebabnya, inflasi dibedakan atas inflasi penawaran, permintaan, dan ekspektasi (Suseno \& Astiyah, 2009).

Pada perekonomian modern saat ini, masalah dan penyebab inflasi adalah sangat kompleks. Berdasarkan teori kuantitas, laju inflasi utamanya disebabkan atau memiliki hubungan dengan laju penawaran uang (Sukirno, 2000). Sementara, saat ini bukan hanya penawaran uang saja yang menyebakan inflasi, melainkan terdapat banyak peubah lain, diantaranya kenaikan harga bahan mentah yang diimpor, kenaikan harga bahan bakar, defisit neraca perdagangan, peningkatan indeks harga perdagangan besar, perubahan suku bunga acuan kegiatan ekonomi dalam negeri, serta perubahan nilai tukar mata uang dalam negeri atas mata uang luar negeri.

a. Uang Beredar

Menurut pandangan ahli-ahli ekonomi (Sukirno, 2000), perubahan dalam penawaran uang atau jumlah uang beredar akan menyebabkan kenaikan harga yang sama tingkatnya dengan tingkat kenaikan penawaran uang. Berdasarkan hasil penelitian yang telah dilakukan oleh Osman dkk. (2014) serta Sutawijaya \& Zulfahmi (2012), menyatakan bahwa penawaran uang memiliki hubungan atau pengaruh yang signifikan terhadap inflasi.

b. Neraca Perdagangan

Pada sistem perekonomian terbuka, suatu negara melibatkan diri dalam perdagangan internasional, yaitu ekspor dan impor, sehingga menimbulkan ruang keluar masuknya valuta asing suatu negara. Neraca perdagangan merupakan nilai dari besaran transaksi perdagangan antara ekspor dan impor. Saat nilai ekspor melebihi nilai impor, maka terjadi surplus neraca perdagangan. Sedangkan saat nilai impor lebih tinggi dibandingkan nilai ekspor, maka terjadi defisit neraca perdagangan. Surplus dan defisit nya neraca perdagangan mempengaruhi neraca pembayaran suatu negara. Jika surplus terjadi, maka valuta asing suatu negara bertambah dan berarti jumlah uang beredar juga bertambah. Sebaliknya, jika defisit terjadi, maka valuta asing suatu negara berkurang karena digunakan untuk menutupi defisit tersebut, sehingga mengurangi jumlah uang beredar (Sukirno, 2000).

c. Nilai Impor

Berdasarkan kebutuhan akan barang yang tidak dapat diproduksi oleh suatu negara, maka diperlukan impor untuk memenuhi kebutuhan tersebut. Nilai impor mencerminkan besarnya pengeluaran suatu negara untuk pemenuhan kebutuhan dan perkembangan perekonomian dalam negaranya. Dikutip dari Asmara (2018), pada November tahun 2018 Indonesia mengalami defisit neraca perdagangan akibat impor migas yang melebihi ekspor nya. Sementara di sisi lain, pada tahun 2005, tarif bahan bakar minyak (BBM) melonjak akibat munculnya kebijakan pemerintah karena naiknya harga minyak dunia pada saat itu. Berdasarkan hal tersebut, nilai impor dianggap mempengaruhi tingkat inflasi karena berkaitan dengan neraca perdagangan, penawaran uang, dan kebijakan pemerintahan suatu negara terhadap laju tingkat inflasi.

d. Nilai Tukar

Pengaruh perubahan nilai tukar meliputi perdagangan luar negeri, yaitu ekspor dan impor (Sutawijaya \& Zulfahmi, 2012) serta berpengaruh terhadap nilai mata uang dalam negeri. Apabila nilai mata uang melemah, maka menyebabkan turunnya daya beli masyarakat serta harga-harga di pasaran cenderung meningkat, begitupun sebaliknya, penguatan nilai mata uang dalam negeri dapat mendorong daya beli masyarakat serta cenderung menurunkan harga-harga di pasaran.

e. Indeks Harga Perdagangan Besar (IHPB)

Indeks harga perdagangan besar atau IHPB mencerminkan perubahan nilai mata uang suatu negara. IHPB digunakan suatu perusahaan untuk menghasilkan barang-barang lainnya (Khalwaty, 2000). Peningkatan harga- 
harga barang dalam pasar pertama (cakupan perdagangan besar) terjadi karena kelebihan permintaan dibandingkan dengan penawaran terhadap barang tersebut antara penjual/pedagang besar pertama dengan pembeli/pedagang besar berikutnya, yang selanjutnya memicu inflasi di tingkat harga-harga perdagangan besar/grosir.

f. Suku Bunga Acuan

Berkaitan dengan penawaran uang, suku bunga merupakan upaya Bank Sentral untuk menekan laju inflasi. Jika tingkat suku bunga dinaikkan, jumlah uang yang beredar akan berkurang karena masyarakat lebih memilih menabung daripada memutarkan uangnya pada sektor-sektor produktif, ataupun sebaliknya (Khalwaty, 2000). Beberapa penelitian yang memperkuat teori ini ialah oleh Julitawaty (2015), Sutawijaya \& Zulfahmi (2012), serta Osman dkk. (2014).

\subsection{Analisis Regresi}

Regresi merupakan suatu jenis analisis yang digunakan untuk menjelaskan hubungan antar peubah respon dan peubah prediktor. Analisis regresi dibedakan atas tiga jenis berdasarkan pola hubungan data yang dihasilkan antar dua peubah atau kurva regresi, yaitu regresi parametrik, semi parametrik, dan non parametrik (Budiantara, 2005). Adapun fungsi umum model regresi ialah sebagai berikut.

$$
y_{i}=f\left(x_{i}\right)+\varepsilon_{i} ; i=1,2, \ldots, n
$$

dengan $y_{i}$ adalah peubah dependen pada respon ke-i, $f\left(x_{i}\right)$ merupakan fungsi regresi yang tidak diketahui, dan $\varepsilon_{i}$ merupakan error atau galat dari peubah acak yang diasumsikan menyebar identik dan independen dengan nilai tengah 0 dan ragam tertentu $\sigma^{2}$ (Eubank, 1999).

\subsection{Recursive Partitioning Regression (RPR)}

RPR berdasarkan konsep estimasi simultan pada set subregion dan asosiasi parameter dengan fungsi yang berbeda di setiap subregion nya merupakan jenis regresi nonparametrik yang menangani data berdimensi tinggi. RPR oleh Friedman (1991) memberikan persamaan sebagai berikut untuk estimasi fungsi $f$ pada persamaan (2.1).

$$
f(x)=\sum_{m=1}^{M} \boldsymbol{a}_{m} \boldsymbol{B}_{m}(x)
$$

dengan fungsi basis $B_{m}$ ialah

$$
\boldsymbol{B}_{m}(x)=\prod_{k=1}^{K_{m}} H\left[\boldsymbol{S}_{k m} \cdot\left(\boldsymbol{x}_{v(k, m)}-\boldsymbol{t}_{k m}\right)\right]
$$

dengan:

$a_{m} \quad=$ koefisien fungsi basis ke- $m$

$M \quad=$ maksimum fungsi basis

$K_{m} \quad=$ derajat interaksi

$H[\eta]=\left\{\begin{array}{l}1 ; \eta \geq 0 \\ 0 ; \text { lainnya }\end{array}=\right.$ fungsi tangga (step function)

$s_{k m}=$ bernilai \pm 1 , mengindikasikan asosiasi letak fungsi tangga

$x_{v(k, m)}=$ peubah prediktor ke- $v$

$t_{k m}=$ nilai knot dari peubah prediktor

Meskipun RPR memiliki kemampuan dalam menangani data berdimensi tinggi, model RPR memiliki kelemahan, yaitu diskontinu pada setiap subregion-nya. Mengatasi hal tersebut, Friedman melakukan modifikasi pada algoritma fungsi $H[\eta]$ menggunakan fungsi truncated spline

$$
b_{q}^{ \pm}(x-t)=[ \pm(x-t)]_{+}^{q}
$$

Selanjutnya, persamaan (2.4) disubstitusi ke persamaan (2.3), sehingga diperoleh persamaan fungsi basis sebagai berikut.

$$
B_{m}^{q}(x)=\prod_{k=1}^{K_{m}}\left[\boldsymbol{S}_{k m} \cdot\left(\boldsymbol{X}_{v(k, m)}-\boldsymbol{t}_{k m}\right)\right]_{+}^{q}
$$

dengan $q=1$ dan tanda + mengindikasikan nilai nol jika argumen bernilai negatif. Beberapa inovasi dilakukan oleh Friedman untuk mengatasi kelemahan RPR, termasuk persamaan (2.5) (Citra, 2017), yaitu tidak menghapus fungsi basis parent dan membatasi perkalian pada masing-masing fungsi basis hanya melibatkan peubah prediktor yang berbeda. 


\subsection{Multivariate Adaptive Regression Splines (MARS)}

MARS merupakan pendekatan regresi nonparametrik multivariat yang menggabungkan prinsip regresi spline dan RPR. MARS mampu menangani data ber-dimensi tinggi, yaitu jumlah peubah prediktor $3 \leq x \leq 20$ dan ukuran data sampel $50 \leq n \leq 1000$ (Friedman, 1991). Beberapa hal yang perlu diperhatikan dalam penggunaan metode analisis MARS ialah sebagai berikut (Citra, 2017).

a. Knot, yaitu nilai peubah prediktor ketika slope suatu garis regresi mengalami perubahan yang dapat didefinisikan sebagai akhir dari sebuah garis regresi dan awal dari sebuah garis yang lain. Setiap titik knot diharapkan memberi kontinuitas dari fungsi basis antar satu region dan region lainnya. Minimum jarak antara knot atau minimum observasi atau amatan (MO) antara knot adalah $0,1,2$, hingga 3 amatan.

b. Fungsi Basis/Basis Function (BF), yaitu suatu fungsi parametrik yang didefinisikan pada tiap region yang digunakan untuk menjelaskan hubungan antara peubah respon dan peubah prediktornya. Fungsi basis ini berupa selang antar knot yang berurutan. Pada umumnya fungsi basis yang dipilih berbentuk polinomial dengan turunan yang kontinu pada setiap titik knot. Maksimum fungsi basis yang diizinkan adalah 2-4 kali jumlah peubah prediktornya.

c. Interaksi, yaitu hubungan korelasi antar peubah (hasil perkalian silang antar peubah yang saling berkorelasi). Jumlah maksimum interaksi (MI) yang diperbolehkan adalah 1, 2, atau 3. Jika MI > 3 akan dihasilkan model yang semakin kompleks dan model akan sulit diinterpretasi

Friedman (1991) memberikan persamaan MARS untuk estimasi fungsi $f$ (2.1)

$$
f(x)=\boldsymbol{a}_{0}+\sum_{m=1}^{M} \boldsymbol{a}_{m} \prod_{k=1}^{K_{m}}\left[\boldsymbol{s}_{k m} \cdot\left(\boldsymbol{x}_{v(k, m)}-\boldsymbol{t}_{k m}\right)\right]_{+}
$$

dengan:

$a_{0} \quad=$ koefisien fungsi basis parent

$a_{m} \quad=$ koefisien fungsi basis ke $-m$

$M \quad=$ maksimum fungsi basis

$K_{m} \quad=$ maksimum derajat interaksi

$s_{k m} \quad=$ bernilai \pm 1

$x_{v(k, m)}=$ peubah prediktor ke- $v$

$t_{k m} \quad=$ nilai knot dari peubah prediktor

Persamaan (2.6) dapat diubah ke dalam bentuk

$$
f(x)=a_{0}+\sum_{K_{m}=1} f_{1}\left(x_{1}\right)+\sum_{K_{m}=2} f_{12}\left(x_{1}, x_{2}\right)+\ldots+\sum_{K_{m}=k} f_{12 \ldots p}\left(x_{1}, x_{2}, \ldots, x_{p}\right)
$$

Misalkan $V(m)=\{v(k, m)\}_{1}^{K_{m}}$ merupakan himpunan peubah dengan $m$ fungsi basis $\left(B_{m}\right)$ pada persamaan (2.6), maka penjumlahan pertama, kedua, dan terakhir pada persamaan (2.7) dijabarkan sebagai berikut.

$$
\begin{aligned}
& f_{1}\left(x_{1 .}\right)=\sum_{K_{m}=1} a_{m} B_{m}\left(x_{1}\right) \\
& f_{12}\left(x_{1}, x_{2}\right)=\sum_{K_{m}=2} a_{m} B_{m}\left(x_{1}, x_{2}\right) \\
& f_{12 . p}\left(x_{1}, x_{2}, \cdots, x_{p .}\right)=\sum_{K_{m}=k} a_{m} B_{m}\left(x_{1}, x_{2}, \cdots, x_{p .}\right)
\end{aligned}
$$

Persamaan (2.8) merupakan penjumlahan semua fungsi basis untuk satu peubah, yang merupakan representasi fungsi univariat. Sementara persamaan (2.9) dan (2.10) merepresentasikan fungsi bivariat dan multivariat, dimana peubah terkait memiliki interaksi yang diduga berpengaruh terhadap peubah respon. Jika kita juga memerhatikan fungsi univariat pada persamaan (2.9) serta fungsi bivariat pada persamaan (2.10), maka persamaan (2.9) dan (2.10) dijabarkan sebagai berikut .

$$
\begin{aligned}
& f_{12}^{*}\left(x_{1}, x_{2}\right)=f_{1}\left(x_{1}\right)+f_{2}\left(x_{2}\right)+f_{12}\left(x_{1}, x_{2}\right) \\
& f_{12 \ldots}{ }^{*}\left(x_{1}, x_{2}, \ldots, x_{p}\right)=f_{1}\left(x_{1}\right)+f_{2}\left(x_{2}\right)+\ldots+f_{p}\left(x_{p .}\right)+f_{12}\left(x_{1}, x_{2}\right)+\ldots+f_{\ldots p}\left(x_{\ldots}, x_{p .}\right)+f_{12 \ldots p}\left(x_{1}, x_{2}, \ldots, x_{p .}\right)
\end{aligned}
$$

(Otok, 2005)

Persamaan (2.6) dalam bentuk matriks dapat dilihat pada persamaan berikut.

$$
\underline{\hat{f}}(\underline{x})=B \underline{a}
$$


dengan:

$$
\begin{aligned}
& \underline{a}=\left(a_{0}, a_{1}, a_{2}, \cdots, a_{M}\right)^{T} \\
& B=\left(\begin{array}{cccc}
1 & \prod_{k=1}^{K}\left[s_{1 m} \cdot\left(x_{v(1, m)}-t_{1 m}\right)\right]_{+} & \cdots & \prod_{k=1}^{K}\left[s_{M m \cdot}\left(x_{v 1(M, m)}-t_{M m}\right)\right]_{+} \\
1 & \prod_{k=1}^{K}\left[s_{1 m} \cdot\left(x_{v 2(1, m)}-t_{1 m}\right)\right]_{+} & \cdots & \prod_{k=1}^{K}\left[s_{M m} \cdot\left(x_{v 2(M, m)}-t_{M m}\right)\right]_{+} \\
\vdots & \vdots & \ddots & \vdots \\
1 & \prod_{k=1}^{K}\left[s_{1 m} \cdot\left(x_{v n(1, m)}-t_{1 m}\right)\right]_{+} & \cdots & \prod_{k=1}^{K}\left[s_{M m \cdot}\left(x_{v m(M, m)}-t_{M m}\right)\right]_{+}
\end{array}\right)
\end{aligned}
$$

(Darmawanti dkk., 2014)

Persamaan (2.13) menghasilkan persamaan (2.14) sebagai penduga $\underline{Y}$

$$
\begin{aligned}
& \underline{\hat{Y}}=\hat{\hat{f}}(\underline{x}) \\
& \underline{\hat{Y}}=B \underline{\hat{a}}
\end{aligned}
$$

(Ampulembang dkk., 2015)

dengan: $\underline{Y}=\left(y_{1}, y_{2}, y_{3}, \ldots, y_{n}\right)^{T}$ dan $\underline{\hat{a}}=\left(B^{T} B\right)^{-1} B^{T} Y$ serta $B$ sebagaimana yang dimaksud pada persamaan $(2.13)$

\subsection{Pemilihan Model MARS}

Pembentukan model MARS meliputi dua tahap, yaitu forward stepwise dan backward stepwise. Pada forward stepwise, dihasilkan fungsi basis hingga $M$ fungsi basis. Fungsi basis yang tidak konstan pada tahap ini selanjutnya dieliminasi menggunakan backward stepwise demi memenuhi konsep parsimoni dengan meminimumkan nilai Generalized Cross Validation (GCV) (Friedman, 1991; Otok, 2005). Hasil dari backward stepwise memberikan kombinasi fungsi basis yang optimal bagi model MARS.

Model yang diperoleh pada backward stepwise bukan merupakan model akhir yang akan digunakan, karena pada tahap tersebut masih diperoleh beberapa kombinasi fungsi basis dengan model yang berbeda. Oleh karena itu, dibutuhkan kriteria pemilihan model MARS yang terbaik untuk mewakili data penelitian. (Friedman, 1991) menggunakan GCV untuk memilih model terbaik.

$$
\operatorname{LOF}\left(\hat{f}_{M}\right)=G C V(M)=\frac{\frac{1}{N} \sum_{i=1}^{N}\left[y_{i}-\hat{f}_{M}\left(x_{i}\right)\right]^{2}}{\left[1-\frac{\tilde{C}(M)}{N}\right]^{2}}
$$

dengan:

$$
\begin{aligned}
& \tilde{C}(M)=C(M)+d \cdot M \\
& C(M)=\operatorname{tr}\left[\left(B^{T} B\right)^{-1} B^{T}+1\right]
\end{aligned}
$$

dengan:

LOF $\quad$ lack-of-fit test

$\hat{f}_{M} \quad=$ penduga fungsi $f$ dengan $M$ fungsi basis

$N \quad=$ ukuran sampel

$C(M) \quad=$ banyaknya parameter yang diestimasi

$d \quad=$ nilai optimal fungsi basis, $2 \leq d \leq 4$

\section{Metode Penelitian}

Penelitian ini merupakan penelitian terapan dengan pendekatan kuantitatif. Data yang digunakan meliputi data tingkat inflasi Indonesia sebagai peubah respon $(\mathrm{Y})$, peubah prediktor nilai impor migas $\left(\mathrm{X}_{1}\right)$, IHPB $\left(\mathrm{X}_{2}\right)$, BI Rate $\left(\mathrm{X}_{3}\right)$, Nilai Tukar IDR-USD $\left(\mathrm{X}_{4}\right)$, Jumlah Uang Beredar $\left(\mathrm{X}_{5}\right)$, dan Neraca Perdagangan Indonesia $\left(\mathrm{X}_{6}\right)$, yang tercatat dari Januari 2005-Desember 2018. Data bersumber dari publikasi Badan Pusat Statistik (2019) dan Bank Indonesia (2019) 


\subsection{Definisi Operasional Peubah}

a. Tingkat Inflasi $(\mathrm{Y})=$ Data yang digunakan ialah Inflasi Umum Indonesia, tercatat setiap bulannya, dalam satuan persen, bersumber dari Indikator Ekonomi Badan Pusat Statistik.

b. Nilai Impor Migas $\left(\mathrm{X}_{1}\right)=$ Data nilai impor migas yang digunakan ialah data yang tercatat setiap bulan, dengan satuan ribu USD, bersumber dari Indikator Ekonomi Badan Pusat Statistik.

c. IHPB $\left(\mathrm{X}_{2}\right)=$ IHPB yang digunakan pada penelitian ini ialah Indeks Umum Tanpa Ekspor dan Impor, tercatat setiap bulannya, dalam satuan indeks, bersumber dari Indikator Ekonomi Badan Pusat Statistik.

d. BI Rate $\left(\mathrm{X}_{3}\right)=$ Suku bunga kebijakan moneter yang ditetapkan oleh Bank Indonesia, tercatat setiap bulannya dalam satuan persen, bersumber dari Statistik Ekonomi dan Keuangan Indonesia (SEKI) oleh Bank Indonesia.

e. Nilai Tukar IDR-USD $\left(\mathrm{X}_{4}\right)=$ Data yang digunakan ialah nilai tukar tengah IDR terhadap USD yang tercatat setiap bulan dengan satuan IDR, bersumber dari SEKI oleh Bank Indonesia.

f. Jumlah Uang Beredar $\left(\mathrm{X}_{5}\right)=$ Jumlah uang beredar yang digunakan pada penelitian ini ialah uang beredar luas (M2), tercatat setiap bulannya, dalam satuan miliar Rupiah, bersumber dari SEKI oleh Bank Indonesia.

g. Neraca Perdagangan Indonesia $\left(\mathrm{X}_{6}\right)=$ Data neraca perdagangan yang digunakan tercatat setiap bulannya dalam satuan Juta USD, bersumber dari Indikator Ekonomi Badan Pusat Statistik.

\subsection{Teknik Analisis}

a. Eksplorasi data tingkat inflasi di Indonesia beserta faktor-faktor yang diduga mempengaruhinya.

b. Melakukan analisis statistika deskriptif pada rangkaian data penelitian.

c. Membuat plot data antara peubah respon dan masing-masing peubah prediktor.

d. Jika plot antar peubah memberikan kurva regresi yang tidak diketahui polanya, maka lanjut ke analisis regresi nonparametrik, yaitu menggunakan Multivariate Adaptive Regression Splines.

e. Membangun model MARS:

1) Menentukan basis fungsi (BF). Maksimum BF merupakan kelipatan 2, 3, hinga 4 kali dari jumlah peubah bebas. Karena peubah bebas yang digunakan pada penelitian ini adalah 6 , maka maksimum BF ialah 12, 18 , dan 24.

2) Menentukan maksimum interaksi (MI), yaitu 1,2, 3. Karena apabila MI lebih dari 3, maka akan menambah kompleksitas model. Penentuan MI sesuai dengan kebutuhan penelitian.

3) Menentukan minimal jumlah pengamatan setiap knots (MO), yaitu 0, 1, 2, dan 3.

f. Mendapatkan model terbaik dengan memerhatikan nilai Generalized Cross Validation (GCV). Semakin kecil nilai GCV, maka semakin baik model tersebut dibandingkan model lainnya.

g. Menentukan faktor-faktor paling berpengaruh terhadap peubah respon.

1) Uji signifikansi bersama $B F$

2) Uji signifikansi parsial BF

h. Kesimpulan

\section{Hasil dan Pembahasan}

\subsection{Analisis Statistika Deskriptif}

Berdasarkan data, tingkat inflasi di Indonesia pernah berada dalam kategori inflasi sedang, yaitu antara 10\%-30\%. Hal tersebut ditunjukkan oleh data tingkat inflasi pada Oktober 2005-September 2006, yakni mencapai nilai maksimum tingkat inflasi di Indonesia. Setelah periode tersebut, tingkat inflasi di Indonesia sempat menurun dan kembali berfluktuasi hingga pada periode Mei 2008-Desember 2008, tingkat inflasi di Indonesia kembali merangkak naik hingga interval 10\%-12\%. Selain hal tersebut, data tingkat inflasi di Indonesia pada bulan-bulan lainnya berada pada kategori rendah, yaitu antara 0\%-10\%. Hal ini ditunjukkan dengan nilai rata-rata tingkat inflasi di Indonesia, yaitu sebesar 6,46\% sesuai Tabel 1 yang menunjukkan statistika deskriptif data tingkat inflasi. Sementara Gambar 1 menunjukkan sebaran data tingkat inflasi Indonesia yang berfluktuasi setiap bulannya serta Gambar 2 menunjukkan 
pola hubungan antara masing-masing peubah prediktor terhadap peubah respon yang cenderung tidak menunjukkan pola hubungan tertentu. Sehingga digunakan regresi nonparametrik, MARS, untuk mengidentifikasi pengaruh hubungan antara peubah prediktor terhadap peubah respon.

Tabel 1. Statistik deskriptif data tingkat inflasi di Indonesia TAHUN 2005-2018

\begin{tabular}{l|rrrrrrr}
\hline & \multicolumn{1}{|c}{ Y } & \multicolumn{1}{c}{ X1 } & \multicolumn{1}{c}{ X2 } & \multicolumn{1}{c}{ X3 } & \multicolumn{1}{c}{ X4 } & \multicolumn{1}{c}{ X5 } & \multicolumn{1}{c}{ X6 } \\
\hline Minimum & 2,41 & $4.090,70$ & 126,87 & 4,25 & $8.508,00$ & $1.012 .144,00$ & $-2.883,60$ \\
Maksimum & 18,38 & $18.297,10$ & 264,92 & 12,75 & $15.227,00$ & $5.760 .046,20$ & $8.755,70$ \\
Rerata & 6,46 & $11.385,79$ & 171,66 & 7,25 & $10.880,88$ & $3.027 .764,30$ & $2.698,22$ \\
Standar Deviasi & 3,50 & $4.008,27$ & 29,55 & 1,96 & $1.965,11$ & $1.455 .908,99$ & $2.558,49$ \\
\hline
\end{tabular}

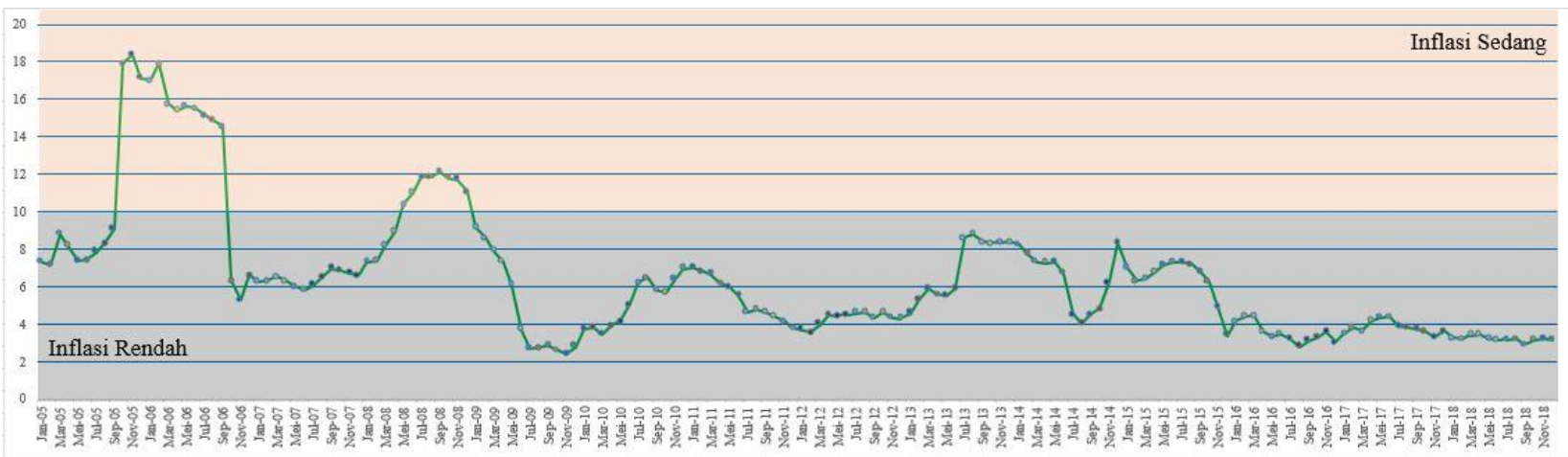

Gambar 1. Plot data tingkat inflasi di Indonesia tahun 2005-2018

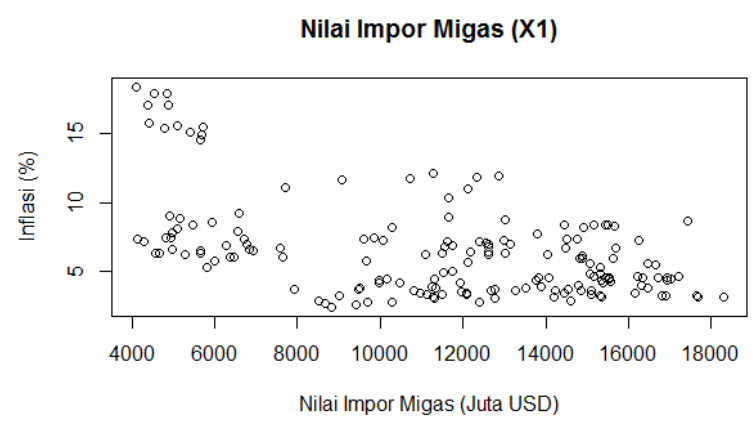

BI Rate (X3)

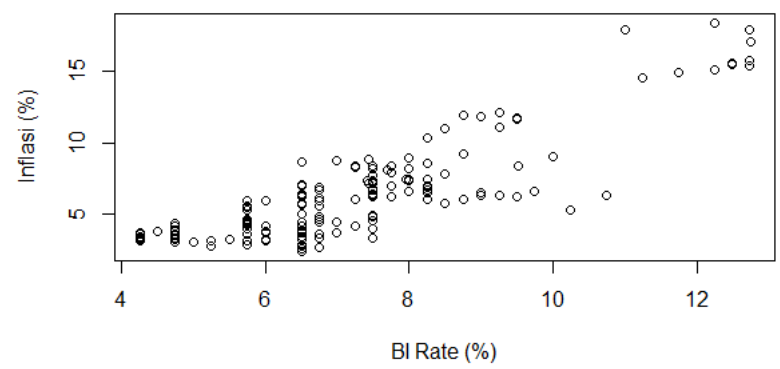

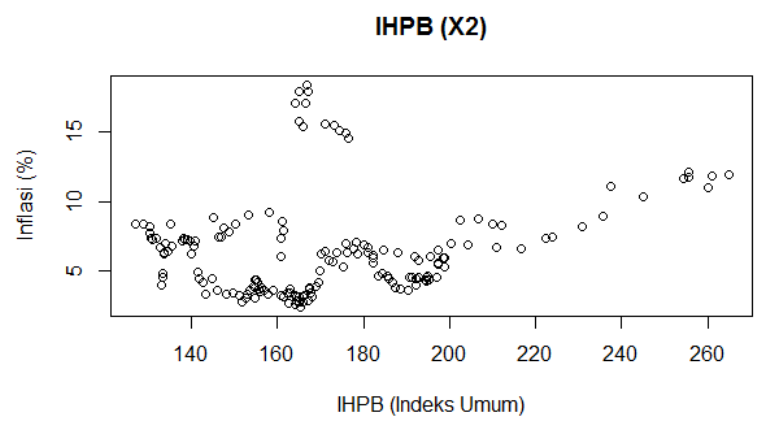

Nilai Tukar IDR-USD (X4)

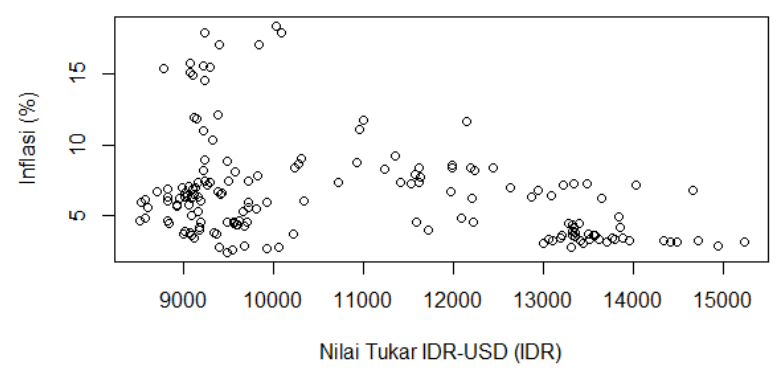



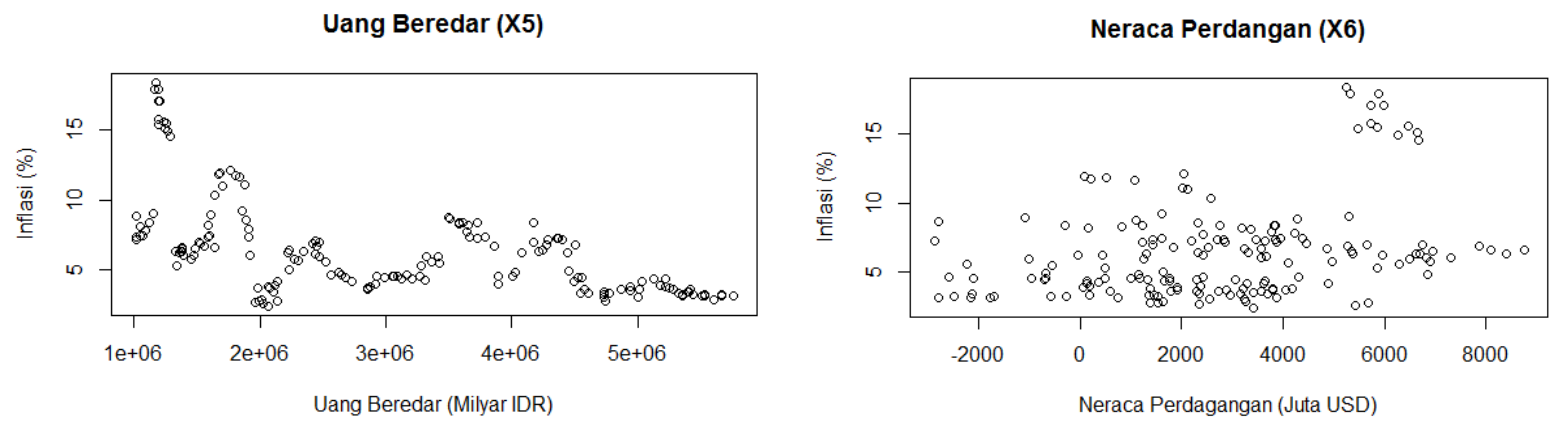

Gambar 2. Pola hubungan antara masing-masing peubah prediktor terhadap peubah respon

\subsection{Pemodelan dan Pemilihan Model Terbaik MARS}

Pada penelitian ini digunakan software Salford Predictive Modeler versi 8.3.0 untuk membangun model MARS berdasarkan kombinasi nilai Fungsi Basis (BF), Maksimum Interaksi (MI), dan Minimum Observasi (MO). Nilai BF, MI, dan MO merupakan yang sebelumnya telah ditentukan. Berdasarkan kombinasi nilai BF, MI, dan MO, maka diperoleh 36 model MARS sesuai pada Tabel 2. Masing-masing model tersebut merupakan model final yang dipilih menurut nilai Generalized Cross Validation (GCV) terkecil.

Berdasarkan kriteria pemilihan model terbaik, yakni model dengan nilai GCV terkecil atau minimum, maka pada Tabel 2 diketahui bahwa model MARS terbaik ialah dengan kombinasi nilai $\mathrm{BF}=24, \mathrm{MI}=3$, dan $\mathrm{MO}=1$. Sehingga model kombinasi $\mathrm{BF}=24, \mathrm{MI}=3$, dan $\mathrm{MO}=1$ merupakan model MARS terbaik untuk memodelkan tingkat inflasi di Indonesia. Adapun model lengkap dari model terbaik tersebut dapat dilihat pada persamaan (4.1).

Tabel 2. Model MARS terbaik menurut kombinasi BF, MI, dan MO

\begin{tabular}{cccc}
\hline BF & MI & MO & GCV \\
\hline & 1 & 0 & 1,47 \\
1 & 1 & 1,29 \\
1 & 2 & 1,52 \\
1 & 3 & 1,41 \\
2 & 0 & 1,61 \\
& 2 & 1 & 1,45 \\
& 2 & 2 & 1,50 \\
& 2 & 3 & 1,60 \\
& 3 & 0 & 1,44 \\
3 & 1 & 1,45 \\
& 3 & 2 & 1,50 \\
3 & 3 & 1,48 \\
\hline & 1 & 0 & 1,42 \\
& 1 & 1 & 1,08 \\
18 & 1 & 2 & 1,31 \\
& 1 & 3 & 1,39 \\
& 2 & 0 & 1,56 \\
& 2 & 1 & 1,04 \\
& 2 & 2 & 1,17 \\
& 2 & 3 & 1,54 \\
& 3 & 0 & 1,25 \\
3 & 1 & 1,04 \\
& 3 & 2 & 1,17 \\
& 3 & 3 & 1,23 \\
\hline
\end{tabular}




\begin{tabular}{cccc}
\hline BF & MI & MO & GCV \\
\hline & 1 & 0 & 1,35 \\
1 & 1 & 0,91 \\
1 & 2 & 1,13 \\
1 & 3 & 1,39 \\
2 & 0 & 1,31 \\
& 2 & 1 & 0,82 \\
& 2 & 2 & 0,93 \\
& 2 & 3 & 1,32 \\
& 3 & 0 & 1,16 \\
& $\mathbf{3}$ & $\mathbf{1}$ & $\mathbf{0 , 7 7}$ \\
& 3 & 2 & 0,86 \\
& 3 & 3 & 1,14 \\
\hline
\end{tabular}

$$
\begin{aligned}
& \hat{Y}=12,26+14,04 * B F 1-1,64 * B F 2+0,08 * B F 3+ \\
& 0,63 * B F 4-0,12 * B F 5+0,25 * B F 6-13,61 * B F 7- \\
& 1,93 E-04 * B F 9+3,07 E-05 * B F 10-1,76 E-05 * B F 14- \\
& 0,17 * B F 16-5,51 E-07 * B F 17-5,67 E-07 * B F 18- \\
& 3,36 E-09 * B F 20+3,04 E-08 * B F 21+1,05 E-08 * B F 22- \\
& 1,66 E-04 * B F 23-6,99 E-07 * B F 24
\end{aligned}
$$

dengan:

\begin{tabular}{|c|c|c|}
\hline Peubah Prediktor & Besar Kontribusi & Kontribusi meminimumkan nilai GCV \\
\hline $\mathrm{X}_{1}$ & $0 \%$ & 0,77 \\
\hline $\mathrm{X}_{2}$ & $40,89 \%$ & 2,62 \\
\hline $\mathrm{X}_{3}$ & $100 \%$ & 11,83 \\
\hline $\mathrm{X}_{4}$ & $13,13 \%$ & 0,96 \\
\hline $\mathrm{X}_{5}$ & $29,53 \%$ & 1,74 \\
\hline$X_{6}$ & $0 \%$ & 0,77 \\
\hline
\end{tabular}

$$
\begin{aligned}
& \text { BF1 }=\max \left(0, X_{3}-10,25\right) ; \\
& \text { BF2 }=\max \left(0,10,25-X_{3}\right) ; \\
& \text { BF3 }=\max \left(0, X_{2}-184,78\right) ; \\
& \text { BF4 }=\max \left(0,184,78-X_{2}\right) ; \\
& \text { BF5 }=\max \left(0, X_{3}-5,75\right) * B F 4 ; \\
& \text { BF6 }=\max \left(0,5,75-X_{3}\right) * B F 4 ; \\
& \text { BF7 }=\max \left(0, X_{3}-11,25\right) ; \\
& \text { BF9 }=\max \left(0, X_{5}-1.270 .380\right) * B F 1 ; \\
& \text { BF10 }=\max \left(0,1.270 .380-X_{5}\right) * B F 1 ; \\
& \text { BF11 }=\max \left(0, X_{3}-7,42\right) ;
\end{aligned}
$$

Berdasarkan persamaan (4.1), terdapat empat peubah prediktor yang mempengaruhi peubah respon, yaitu peubah IHPB $\left(\mathrm{X}_{2}\right)$, BI Rate $\left(\mathrm{X}_{3}\right)$, Nilai Tukar IDR terhadap USD $\left(\mathrm{X}_{4}\right)$, dan Uang Beredar $\left(\mathrm{X}_{5}\right)$, serta terdapat sebanyak $18 \mathrm{BF}$ yang berkontribusi dalam pembentukan model.

Tabel 3. Kontribusi Peubah Prediktor terhadap Peubah Respon

Dari beberapa peubah prediktor yang digunakan untuk memodelkan tingkat inflasi, $\mathrm{X}_{1}$ merupakan peubah Nilai Impor Migas dan $\mathrm{X}_{6}$ merupakan Neraca Perdagangan, tidak masuk ke dalam model, karena memberikan kontribusi minimum untuk meningkatkan kebaikan model. Sehingga $\mathrm{X}_{1}$ dan $\mathrm{X}_{6}$ memiliki kontribusi 0\% terhadap Y. Sementara itu, $\mathrm{X}_{3}$ memiliki kontribusi paling besar terhadap $\mathrm{Y}$ dalam model yang digunakan, yaitu dengan kontribusi sebesar 
100\% dibandingkan dengan peubah prediktor lainnya. Besarnya kontribusi setiap peubah prediktor terhadap pembentukan model dilihat dari kontribusi peubah tersebut untuk meminimumkan nilai GCV.

\subsection{Interprestasi Model MARS}

1) $\mathrm{BF} 1=\max \left(0, \mathrm{X}_{3}-10.25\right)$

BF1 dengan koefisien 14,04 berarti bahwa setiap peningkatan satu satuan BF1 akan menyebabkan tingkat inflasi di Indonesia bertambah sebesar 14,04 persen, dengan fungsi basis lainnya dianggap konstan. BF1 akan bernilai $\left(\mathrm{X}_{3}-10,25\right)$ jika nilai BI Rate lebih besar dari 10,25 persen, dan sebaliknya jika BI Rate bernilai lebih kecil dari atau sama dengan 10,25 persen, maka BF1 akan bernilai 0 atau tidak bermakna.

2) $\mathrm{BF} 2=\max \left(0,10,25-X_{3}\right)$

BF2 dengan koefisien -1,64 berarti bahwa setiap peningkatan satu satuan BF2 akan menyebabkan tingkat inflasi di Indonesia berkurang sebesar 1,64 persen, dengan fungsi basis lainnya dianggap konstan. BF2 akan bernilai $\left(10,25-\mathrm{X}_{3}\right)$ jika nilai BI Rate lebih kecil dari 10,25 persen, dan sebaliknya jika BI Rate bernilai lebih besar dari atau sama dengan 10,25 persen, maka BF2 akan bernilai 0 atau tidak bermakna.

3) $\mathrm{BF3}=\max \left(0, X_{2}-184,78\right)$

BF3 dengan koefisien 0,08 berarti bahwa setiap peningkatan satu satuan BF3 akan menyebabkan tingkat inflasi di Indonesia bertambah sebesar 0,08 persen, dengan fungsi basis lainnya dianggap konstan. BF3 akan bernilai $\left(\mathrm{X}_{2}-184,78\right)$ jika nilai IHPB lebih besar dari 184,78 indeks umum, dan sebaliknya jika IHPB bernilai lebih kecil dari atau sama dengan 184,78 indeks umum, maka BF3 akan bernilai 0 atau tidak bermakna.

4) $\mathrm{BF} 4=\max \left(0,184,78-\mathrm{X}_{2}\right)$

BF4 dengan koefisien 0,63 berarti bahwa setiap peningkatan satu satuan BF4 akan menyebabkan tingkat inflasi di Indonesia bertambah sebesar 0,63 persen, dengan fungsi basis lainnya dianggap konstan. BF4 akan bernilai $\left(184,78-\mathrm{X}_{2}\right)$ jika nilai IHPB lebih kecil dari 184,78 indeks umum, dan sebaliknya jika IHPB bernilai lebih besar dari atau sama dengan 184,78 indeks umum, maka BF4 akan bernilai 0 atau tidak bermakna.

5) $\mathrm{BF} 5=\max \left(0, \mathrm{X}_{3}-5,75\right) * \mathrm{BF} 4$

BF5 dengan koefisien - 0,12 berarti bahwa setiap peningkatan satu satuan BF5 akan menyebabkan tingkat inflasi di Indonesia berkurang sebesar 0,12 persen, dengan fungsi basis lainnya dianggap konstan. BF5 akan bernilai $\left(\left(\mathrm{X}_{3}-5,75\right) * \mathrm{BF} 4\right)$ jika nilai BI Rate lebih besar dari 5,75 persen dan jika nilai IHPB lebih kecil dari 184,78 indeks umum. Selain nilai tersebut, BF5 akan bernilai 0 atau tidak bermakna.

6) $\mathrm{BF} 6=\max \left(0,5,75-\mathrm{X}_{3}\right) * \mathrm{BF} 4$

BF6 dengan koefisien 0,25 berarti bahwa setiap peningkatan satu satuan BF6 akan menyebabkan tingkat inflasi di Indonesia sebesar 0,25 persen, dengan fungsi basis lainnya dianggap konstan. BF6 akan bernilai $\left(\left(5,75-\mathrm{X}_{3}\right) * \mathrm{BF} 4\right)$ jika nilai BI Rate dan IHPB lebih kecil dari 5,75 persen dan 184,78 indeks umum. Selain nilai tersebut, BF6 akan bernilai 0 atau tidak bermakna.

7) BF7 $=\max \left(X_{3}-11,25\right)$

BF7 dengan koefisien -13,61 berarti bahwa setiap peningkatan satu satuan BF7 akan menyebabkan tingkat inflasi di Indonesia berkurang sebesar 13,61 persen, dengan fungsi basis lainnya dianggap konstan. BF7 akan bernilai $(X 3-11,25)$ jika nilai BI Rate lebih besar dari 11,25 persen, dan sebaliknya jika BI Rate bernilai kurang dari atau sama dengan 11,25 persen, maka BF7 akan bernilai 0 atau tidak bermakna.

\section{8) $\mathrm{BF} 9=\max \left(0, \mathrm{X}_{5}-1.270 .380\right) * \mathrm{BF} 1$}

BF9 dengan koefisien -1,93E-04 berarti bahwa setiap peningkatan satu satuan BF9 akan menyebabkan tingkat inflasi di Indonesia berkurang sebesar 1,93E-04 persen, dengan fungsi basis lainnya dianggap konstan. BF9 akan bernilai $\left(\left(\mathrm{X}_{5}-1.270 .380\right) * \mathrm{BF} 1\right)$ jika nilai Uang Beredar dan BI Rate lebih besar dari 1.270.380 milyar IDR dan 10,25 persen. Selain nilai tersebut, BF9 akan bernilai 0 atau tidak bermakna.

9) $\mathrm{BF10}=\max \left(0,1.270 .380-\mathrm{X}_{5}\right) * \mathrm{BF} 1$

BF10 dengan koefisien 3,07E-05 berarti bahwa setiap peningkatan satu satuan BF10 akan menyebabkan tingkat inflasi di Indonesia bertambah sebesar 3,07E-05 persen, dengan fungsi basis lainnya dianggap konstan. BF10 akan bernilai (1.270.380- $\mathrm{X}_{5}$ ) jika nilai Uang Beredar lebih kecil dari 1.270.380 milyar IDR dan jika nilai BI Rate lebih besar dari 10,25 persen. Selain nilai tersebut, BF10 akan bernilai 0 atau tidak bermakna.

10) $\mathrm{BF} 14=\max \left(0,2.217 .590-\mathrm{X}_{5}\right) * \mathrm{BF} 12$

BF14 dengan koefisien -1,76E-05 berarti bahwa setiap peningkatan satu satuan BF14 akan menyebabkan tingkat inflasi di Indonesia berkurang sebesar 1,76E-05 persen, dengan fungsi basis lainnya dianggap konstan. 
BF14 akan bernilai $\left(\left(2.217 .590-\mathrm{X}_{5}\right) * \mathrm{BF} 12\right)$ jika nilai Uang Beredar dan BI Rate lebih kecil dari 2.217.590 milyar IDR dan 7,42 persen. Selain nilai tersebut, BF14 akan bernilai 0 atau tidak bermakna.

11) $\mathrm{BF} 16=\max \left(0,180,12-\mathrm{X}_{2}\right) * \mathrm{BF} 2$

BF16 dengan koefisien -0,17 berarti bahwa setiap kenaikan satu satuan BF16 akan menyebabkan tingkat inflasi di Indonesia berkurang sebesar 0,17 persen, dengan fungsi basis lainnya dianggap konstan. BF16 akan bernilai $\left(\left(180,12-\mathrm{X}_{2}\right) * \mathrm{BF} 2\right)$ jika nilai IHPB dan BI Rate lebih kecil dari 180,12 indeks umum dan 10,25 persen. Selain nilai tersebut, BF16 akan bernilai 0 atau tidak bermakna.

12) $\mathrm{BF17}=\max \left(0, \mathrm{X}_{5}-3.506 .570\right) * \mathrm{BF} 2$

BF17 dengan koefisien -5,51E-07 berarti bahwa setiap kenaikan satu satuan BF17 akan menyebabkan tingkat inflasi di Indonesia berkurang sebesar 5,51E-07 persen, dengan fungsi basis lainnya dianggap konstan. BF17 akan bernilai $\left(\left(\mathrm{X}_{5}-3.506 .570\right) * \mathrm{BF} 2\right)$ jika nilai Uang Beredar lebih besar dari 3.506.570 milyar IDR dan jika nilai BI Rate lebih kecil dari 10,25 persen. Selain nilai tersebut, BF17 akan bernilai 0 atau tidak bermakna.

13) $\mathrm{BF18}=\max \left(0,3.506 .570-\mathrm{X}_{5}\right) * \mathrm{BF} 2$

BF18 dengan koefisien -5,67E-07 berarti bahwa setiap kenaikan satu satuan BF18 akan menyebabkan tingkat infasi di Indonesia berkurang sebesar 5,67E-07 persen, dengan fungsi basis lainnya dianggap konstan. BF18 akan bernilai ((3.506.570- $\left.\mathrm{X}_{5}\right) *$ BF2) jika nilai Uang Beredar dan BI Rate lebih kecil dari 3.506.570 milyar IDR dan 10,25 persen. Selain nilai tersebut, BF18 akan bernilai 0 atau tidak bermakna.

14) $\mathrm{BF} 20=\max \left(0,12.440-\mathrm{X}_{4}\right) * \mathrm{BF} 17$

BF20 dengan koefisien -3,36E-09 berarti bahwa setiap kenaikan satu satuan BF20 akan menyebabkan tingkat inflasi di Indonesia berkurang sebesar 3,36E-09 persen, dengan fungsi basis lainnya dianggap konstan. BF20 akan bernilai $\left(\left(12.440-\mathrm{X}_{4}\right) * \mathrm{BF} 17\right)$ jika Nilai Tukar IDR terhadap USD dan BI Rate lebih kecil dari 12.440 IDR dan 10,25 persen, serta jika nilai Uang Beredar lebih besar dari 3.506.570 milyar IDR. Selain nilai tersebut, BF20 akan bernilai 0 atau tidak bermakna.

15) $\mathrm{BF} 21=\max \left(0, X_{5}-4.546 .740\right) * B F 16$

BF21 dengan koefisien 3,04E-08 berarti bahwa setiap kenaikan satu satuan BF21 akan menyebabkan tingkat inflasi di Indonesia bertambah sebesar 3,04E-08 persen, dengan fungsi basis lainnya dianggap konstan. BF21 akan bernilai $\left(\left(\mathrm{X}_{5}-4.546 .740\right) * \mathrm{BF} 136\right.$ jika nilai Uang Beredar lebih besar dari 4.546 .740 milyar IDR serta jika nilai IHPB dan BI Rate lebih kecil dari 180,12 indeks umum dan 10,25 persen. Selain nilai tersebut, BF21 akan bernilai 0 atau tidak bermakna.

16) $\mathrm{BF} 22=\max \left(0,4.546 .740-\mathrm{X}_{5}\right) * \mathrm{BF} 16$

BF22 dengan koefisien 1,05E-08 berarti bahwa setiap kenaikan satu satuan BF22 akan menyebabkan tingkat inflasi di Indonesia bertambah sebesar 1,05E-08 persen, dengan fungsi basis lainnya dianggap konstan. BF22 akan bernilai $\left(\left(4.546 .740-\mathrm{X}_{5}\right) * \mathrm{BF} 16\right)$ jika nilai Uang Beredar, IHPB, serta BI Rate lebih kecil dari 4.546 .740 milyar IDR, 180,12 indeks umum, serta 10,25 persen. Selain nilai tersebut, BF22 akan bernilai 0 atau tidak bermakna.

17) $B F 23=\max \left(0, X_{5}-4.404 .090\right) * B F 11$

BF23 dengan koefisien -1,66E-04 berarti bahwa setiap kenaikan satu satuan BF23 akan menyebabkan tingkat inflasi di Indonesia berkurang sebesar 1,66E-04 persen, dengan fungsi basis lainnya dianggap konstan. BF23 akan bernilai $\left(\left(\mathrm{X}_{5}-4.404 .090\right) * \mathrm{BF} 11\right)$ jika nilai Uang Beredar dan BI Rate lebih besar dari 4.404.090 milyar IDR dan 7,42 persen. Selain nilai tersebut, BF23 akan bernilai 0 atau tidak bermakna.

\section{8) $\mathrm{BF} 24=\max \left(0,4.404 .090-\mathrm{X}_{5}\right) * \mathrm{BF} 11$}

BF24 dengan koefisien -6,99E-07 berarti bahwa setiap kenaikan satu satuan BF24 akan menyebabkan tingkat inflasi di Indonesia berkurang sebesar 6,99E-07 persen, dengan fungsi basis lainnya dianggap konstan. BF24 akan bernilai $\left(\left(4.404 .090-\mathrm{X}_{5}\right) * \mathrm{BF} 11\right)$ jika nilai Uang Beredar kurang dari 4.404.090 milyar IDR, dan jika nilai BI Rate lebih besar dari 7,42 persen. Selain nilai tersebut, BF23 akan bernilai 0 atau tidak bermakna.

\section{Kesimpulan}

Berdasarkan hasil analisis menggunakan MARS, dapat diketahui bahwa terdapat empat dari enam peubah prediktor yang digunakan, mempengaruhi peubah respon. Peubah tersebut ialah IHPB $\left(\mathrm{X}_{2}\right)$, BI Rate $\left(\mathrm{X}_{3}\right)$, Nilai Tukar IDR terhadap USD $\left(\mathrm{X}_{4}\right)$, dan Uang Beredar $\left(\mathrm{X}_{5}\right)$. Hasil juga menunjukkan bahwa model MARS dengan $\mathrm{BF}=24$ dan $\mathrm{MO}=1$, melibatkan interaksi hingga tiga peubah prediktor terhadap respon, merupakan model terbaik untuk memodelkan data tingkat inflasi di Indonesia dengan nilai GCV terkecil, yaitu 0,77. Sementara berdasarkan 
kontribusi peubah, $\mathrm{X}_{3}$ merupakan peubah prediktor yang paling berpengaruh terhadap peubah respon, disusul oleh $\mathrm{X}_{2}$, $\mathrm{X}_{5}$, dan terakhir oleh $\mathrm{X}_{4}$.

\section{References}

Ampulembang, A. P., Otok, B. W., Rumiati, A. T., \& Budiasih. (2015). Bi-Responses Nonparametric Regression Model Using MARS and Its Properties. 9(29), 1417-1427.

Asmara, C. G. (2018). November 2018, Defisit Migas Makin Bengkak Jadi Rp 176 T. Retrieved from CNBC Indonesia website: https://www.cnbcindonesia.com/market/20181217115103-17-46688/november-2018-defisitmigas-makin-bengkak-jadi-rp-176-t

Badan Pusat Statistik. (2018). Inflasi (Umum) Indonesia Berdasarkan Tahunan dan Bulanan Tahun 2005-2017. Retrieved April 29, 2018, from Badan Pusat Statistik Indonesia website: bps.go.id

Badan Pusat Statistik. (2019). Indikator Ekonomi. Retrieved April 4, 2019, from https://bps.go.id/publication.html?Publikasi\%5BtahunJudul\%5D=\&Publikasi\%5BKataKunci\%5D=Indikator+e konomi\&yt0=Tampilkan

Bank Indonesia. (2019). Metadata Statistik Ekonomi dan Keuangan Indonesia (SEKI). Retrieved April 4, 2019, from https://www.bi.go.id/id/statistik/metadata/seki/Contents/Default.aspx

Budiantara, I. N. (2005). Model Keluarga Spline Polinomial Truncated dalam Regresi Semiparametrik ( Model of Truncated Polynomial Spline family in Semiparametric Regression ). Berkala MIPA, 15(3), 55-61.

Citra, P. (2017). Association Mapping SNP - Fenotipe Menggunakan Metode Multivariate Adaptive Regression Spline (MARS). Institut Pertanian Bogor.

Darmawanti, N. D., Supati, \& Safitri, D. (2014). Pemodelan Indeks Harga Saham Gabungan (IHSG) Menggunakan Multivariate Adaptive Regression Splines (MARS). Gaussian, 3(4), 771-780. Retrieved from http://ejournals1.undip.ac.id/index.php/gaussian

Eubank, R. L. (1999). Nonparametric Regression and Spline Smoothing (2nd ed.). New York: Marcel Dekker.

Friedman, J. H. (1991). Multivariate Adaptive Regression Splines. Annals of Statistics, 19(1), 1-67. https://doi.org/10.1214/aos/1176347963

Julitawaty, W. (2015). Inflation Analysis and Interest Rate in Indonesian. Int J Econ Manag Sci, 4(6), 4-6. https://doi.org/10.4172/21626359.1000257

Khalwaty, T. (2000). Inflasi dan Solusinya. Jakarta: PT Gramedia Pustaka Utama.

Osman, I., Hashim, M. J., \& Elias, N. L. (2014). The Determinants of Inflation in Malaysia. 3rd International Conference on Accounting, Business and Economics.

Otok, B. W. (2005). Klasifikasi Perbankan dengan Pendekatan CART dan MARS. Widya Manajemen \& Akuntansi, $5(1), 50-62$.

Sukirno, S. (2000). Makroekonomi Modern: Perkembangan Pemikiran Dari Klasik Hingga Keynesian Baru. Jakarta: Raja Grafindo Persada.

Suseno, \& Astiyah, S. (2009). Inflasi. In Seri Kebanksentralan. Jakarta: Pusat Pendidikan dan Studi Kebanksentralan (PPSK) Bank Indonesia.

Sutawijaya, A., \& Zulfahmi. (2012). Pengaruh Faktor-faktor Ekonomi Terhadapa Inflasi di Indonesia. Organisasi Dan Manajemen, 8(2), 85-101. 